Jurnal Pendidikan Dasar, 9 (1), Juni 2021

\title{
BAHASA INGGRIS DI MASA PANDEMI: KENDALA PEMBELAJARAN DI SDN AENGDAKE I SUMENEP
}

\author{
Akhmad Feri Fatoni $^{1}$, Tita Tanjungsari ${ }^{2}$, Emdat Suprayitno $^{3}$ \\ ${ }^{1,2,3}$ Universitas Wiraraja \\ Jl. Raya Sumenep-Pamekasan KM. 05 Patean, Panitian Utara, Patean, Batuan, Kabupaten Sumenep, \\ Jawa Timur 69451 \\ akhmadferi@wiraraja.ac.id ${ }^{1}$, titatanjungfkip@wiraraja.ac.id ${ }^{2}$, emdat@wiraraja.ac.id
}

\begin{abstract}
The Covid-19 pandemic that has hit the world requires the education proces $\mathrm{s}$ to be carried out innovatively, including the education process in Indonesia. At the el ementary schoollevel, the use of online learning is recommended by using a platform with a simple operating system such as WhatssApp. The application of online learning requires the readiness of various parties, both from schools, office holders, students, a nd parents. This research was conducted in grade IV of SDN Aengdake I using qualita tive research methods (case studies). This study aimed to describe the obstacles or diff iculties faced by teachers and students in learning English online at SDN Aengdake I.I $\mathrm{n}$ general, there were two factors that underlie the obstacles in learning English online at SDN AengdakeI, they were management and technical factors. In terms of managem ent factors, teachers had difficulty using innovative teaching methods, limited teaching time, and many students lack of discipline in learning process. In technical factor, the economic condition of the family affected the success of online teaching and learning.
\end{abstract}

Keywords: Difficulties of online learning, English learning, Grade IV students of SDN Aengdake I

\begin{abstract}
Abstrak: Pandemi Covid-19 yang melandaseluruhbelahanduniamengharuskan proses pendidikan berlangsung secara inovatif, termasuk proses pendidikan di Indonesia. Pada level sekolah dasar (SD), penggunaan media pembelajaran jarak jauh (daring) disarankan menggunakan platform dengan system operasi sederhana semisal WhatssApp. Penerapan pembelajaran daring ini tentu menuntut kesiapan berbagai pihak, baik dari sekolah, pemangku jabatan, peserta didik, dan orang tua siswa. Penelitian ini dilaksanakan di kelas IV SDN Aengdake I dengan menggunakan metode penelitian kualitatif (studi kasus). Penelitian ini bertujuan untuk mendeskipsikan kendala atau kesulitan-kesulitan yang dihadapi guru dan siswa dalam pembelajaran bahasa Inggris secara daring di SDN Aengdake I Sumenep. Secara umum, terdapat dua faktor yang melandasi kendala dalam pembelajaran bahasa Inggris secara daring di SDN Aengdake I, yaitu faktor manajemen dan teknis. Dalam faktor manajemen, guru kesulitan menggunakan metode pengajaran inovatif, memiliki keterbatasan waktu mengajar, dan banyak siswa kurang disiplin dalam belajar. Secara teknis, kondisi perekonomian keluarga mempengaruhi keberhasilan belajar mengajar secara daring.
\end{abstract}

Kata Kunci: Kendala pembelajaran daring, Pembelajaran bahasa Inggris, Siswa kela s IV SDN Aengdake I Sumenep

15| J P D, p- I S S N : 2252 - 8156 , e - I S S N : $2579-3993$ 
$\Lambda_{\text {seluruh proses kehidupan manusia }}^{\text {wal tahun } 2020 \text { adalah masa dimana }}$ dipaksa untuk berubah. Pasalnya, pada saat itu corona virus mulai masuk dan merebak di Indonesia. Perubahan tatanan kehidupa n manusia berdampak pada setiap lini, uta manya bidang pendidikan. Dalam dunia pe ndidikan, proses belajar mengajar harus dil aksanakan dengan metode daring (jarak jau h) menggunakan berbagai media atau platf orm. Innovasi baik oleh pihak sekolah, sis wa, wali siswa, maupun pemangku jabatan lain sangat dibutuhkan untuk menanggulan gi segala keterbatasan yang diakibatkan ole h pandemi virus corona ini (Yuliani, 2020)

Disadari bahwa pembelajaran jarak jauh (daring) merupakan hal baru yag harus dijalani dalam dunia pendidikan. Pelaksanaan pendidikan pada level sekolah dasar sebelum pandemi, pengajaran daring tidak pernah dilaksanakan. Seluruh pengajar pada level sekolah dasar hampir menggunakan metode tatap muka langsung. Oleh karenanya pada saat kebijakan mengajar secara daring, sangat diperlukan adaptasi terhadap kondisi KBM yang diajarkan. Bazimaziki (2020) mengatakan bahwa perunbahan metode pengajaran luring menjadi daring memiliki masalah yang lebih kompleks apabila dalam pembelajaran harus mencakup nilai etika, berfikir kritis dan analitis, serta keterampilan berkomunikasi (Pohan, 2020)
Hingga akhir tahun 2020, pelaksana an kegiatan belajar mengajar masih tetap $\mathrm{m}$ enngunakan metode daring (jarak jauh). Ke bijakan pelaksanaan KBM secara daring in i didasarkan pada surat Edaran Kementrian Pendidikan dan Kebudayaan Nomor 4 Tah un 2020 tentang pelaksanaan pendidikan p ada masa pandemi covid-19. Tentu saja pro ses KBM ini merupakan hal baru yang past i membawa faktor-faktor penghambat pros es transfer ilmu didalamnya.

Proses belajar mengajar yang dilaksanakan di SDN Aengdake I sepenuhnya mematuhi peraturan pemerintah yang melarang kegiatan tersebut dilaksanakan secara tatap muka. Menurut penuturan pihak sekolah, kegiatan belajar mengajar mayoritas berlangsung dengan menggunakan platform WhatssApp. Penggunaan platform ini karena mayoritas guru dan siswa di sekolah tersebut telah familiar dengan penggunaan WhatssApp da lam kehidupan sehari-hari (Ramadhani, 2020)

Bahasa Inggris sebagai mata pelajaran yang tergolong sulit untuk siswa sekolah dasar membawa serta kesulitankesulitan tersendiri dalam pembelajaran jarak jauh, terlebih bila materi yang diajarkan adalah kosa kata. Kosa kata yang dipelajari dalam bahasa Inggris seluruhnya berbeda dengan kosa kata yang siswa ketahui dalam bahasa Indonesia sebagai 16| J P D, p - I S S N : 2252-8156, e - IS S N : 2579-3993 
bahasa ibu. Oleh karenanya sangat dibutuhkan keterampilan guru pengajar dalam mengajar secara daring agar siswa dapat menghafal kosa kata bahasa Inggris secara efektif.

Pemberian mata pelajaran bahasa Inggris pada level sekolah dassar sangat dibutuhkan. Aedi\&Amaliyah (2017) mengatakan bahwa menghadapi zaman globalisasi yang serba instant ini, seorang anak pada level sekolah dasar telah dituntut untuk bersaing dalam sebuah mata pelajaran global, yaitu bahasa Inggris

Tantangan yang dihadapi guru dalam sistem pembelajaran daring tergolong kompleks, mulai dari pra-kegiatan hingga inti kegiatan pembelajaran. Huang dkk. (2020) menyebutkan tiga tantangan utama yang dihadapi guru dalam metode pembelajaran daring. Pertama, waktu yang guru miliki dala menyiapkan/menyesuaikan materi pembelajaraan luring menjadi daring terbatas; kedua, interaksi guru dan siswa selama proses KBM terbatas; ketiga, diperlukan usaha dan innovasi lebih dalam pendekatan pedagogi agar memotivasi dan mengaktifkan siswa dalam pembelajaran secara daring. Disisi lain, Byun\&Slavin (2020) mengatakan bahwa dimungkinkan terjadi ketidakseibangan pendidikan yang didapat masing-masing siswa yang disebabkan pengaruh keluarga dan permasalahan finansial meskipun fasilitas sekolah dan kurikulum nasional secara daring memadai.

Berkaitan dengan keterampilan mengggunakan platform WhatssApp, siswa kelas IV SDN Aengdake I mayoritas telah piawai menjalankannya. Mereka telah terbiasa berkomunikasi baik secara individu maupun berkolompok dalam aplikasi tersebut. Sehingga mereka dengan senang hati merespon kebijakan sekolah untuk melaksanakan proses KBM dalam platform WhatssApp. Alasan tersebut yang mendasari peneliti memilih siswa kelas IV SDN Aengdake I sebagai subjek penelitian.

Berdasarkan uraian diatas, dapat disimpulkan tujuan penelitian ini adalah untuk untukmendeskipsikan kendala atau kesulitan-kesulitan yang dihadapi guru dan siswa dalam pembelajaran bahasa Inggris secara daring di SDN Aengdake I Sumenep. Sehingga diharapkan akan dihasilkan inovasi untuk menanggulangi kesulitan-kesilutan tersebut pada kegiatan belajar mengajar secara daring di waktu mendatang.

\section{METODE}

Metode yang digunakan dalam penelitian ini dalah kualitatif berjenis studi kasus (case study) dengan tujuan untuk mengidentifikasi dan mendiskripsikan 
kendala-kendala yang dihadapi guru dan siswa dalam proses pembelajaran Bahasa Inggris secara daring pada siswa kelas IV SDN Aengdake I. Kendala-kendala atau kesulitan tersebut diidentifikasi, dianalisis, dan dideskripsikan.

Subjek penelitian ini adalah guru pengajar bahasa Inggris dan siswa kelas IV SDN Aendake I. Penelitian dilaksakan pada semeter ganjil tahun ajaran 20202021.

Peneliti melaksanakan observasi proses pembelajaran bahasa Inggris dalam satu semester melalui platform WhatssApp. Peneliti juga melaksanakan dokumentasi dan wawancara kepada guru dan siswa secara daring via WhatssApp.

Untuk mendapat kesimpulan data hasil observasi, dokumentasi, dan wawancara dianalisis menggunakan triangulasi. Menurut Sugiyono (2007), triangulasi adalah sebuah metode pengukuran untuk meningkatkan pemahaman peneliti terhadap data dan fakta yang dimiliki.

\section{HASIL DAN PEMBAHASAN}

Rangkaian penelitian yang dilakukan oleh peneliti dimulai dengan wawancara dengan guru pengajar bahasa Inggris dan siswa kelas IV SDN Aengdake I. Beberapa pertanyaan yang ditanyakan seputar manajemen dan teknis pelaksanaan kegiatan KBM secara daring dengan mencoba membandingkannya dengan proses KBM secara luring.

a. Metode pengajaran

Secara manajemen pada kegiatan KBM luring, guru dapat brekreasi dengan menggunakan beberapa metode pengajaran sesuai dengan materi yang diajarkan, misalnya guru dapat mengguakan flascard untuk mengajarkan vocabulary atau kosa kata. Namun guru tidak dapat menggunakan metode ini dalam pembelajaran secara daring. Sehingga proses $\mathrm{KBM}$ praktis berlangsung dengan teacher centre. Secara teknis, guru menemui kendala pada saat memberi penjelasan materi yang sedang diajarkan. Pembagian kesempatan antara penjelasan baik secaa tulis maupun pemberian pesan suara dari guru ke siswa dan dari siswa ke guru sering kali terjadi kerancuan. Sehingga seringkali terjadi miskomunikasi antara guru dan siswa.

Pelakasanaan pembelajaran secara daring melalui platform WhatssApp yang dilaksanakan oleh guru SDN Aengdake I tidak memungkinkan terjadinya pembagian kelompok diantara siswa. Tidak terjadi diskusi-diskusi kelompok diantara siswa yang dapat menumbuhkan kratifitas serta pemahaman siswa terhadap materi yang diajarkan. 


\section{b. Durasi/waktu pengajaran}

Proses pembelajaran bahasa Inggris yang terjadi di SDN Aendake I sering kali terkendala durasi waktu yang dimiliki. Sebagai contoh adalah ketikaguru memberikan materi part of body (bagian tubuh). Guru tidak dapat secaralangsung memberikan refleksi terhadap pemahaman siswa yang dibuktikan dengan tugas individu. Akibatnya, banyak diantara siswa yang salah dalam mengartikan nama-nama anggota tubuh manusia. Sebagai contoh, banyak siswa sering tertukar antara bahasa Inggris dagu (chin) dengan pipi (cheek). Kosa kata lain yang sering tertukar adalah telinga (ear) dan mata (eye). Kesalahankesalahan ini tidak dapat secara langsung dikoreksi setelah proses penugasan dikarenakan proses dan durasi waktu yang ada dalam pembelajaran secara daring terbatas (Ariyana, 2018).

Guru juga tidak dapat memberikan pujian atau sanksi bagi siswa dalam mengerjakan tugas. Pada proses pembelajaran tatap muka (luring), guru di SDN Aengdake I biasanya memberikan pujian seperti kata "bagus,pintar,dsb".

c. Kedisiplinan

Selama proses pembelajaran secara daring berlangsung, guru tidak dapat memonitor kondisi siswa. Sehingga pertanyaan-pertanyaan yang diberikan guru melalui platform WhatssApp seringkali diabaikan oleh siswa. Sebagai contoh pada materi berhitung angka (number). Ketika guru meminta siswa berhitung dalam bahasa Inggris dengan mengirimkan pesan suara (voice note), hanya $50 \%$ dari jumlah siswa yang menjawab.

Kreatifitas siswa kurang nampak selama kegiatan belajar mengajar secara daring. tugas-tugas yang diberikan terkadang dikerjakan oleh wali mereka masing-masing. Sehingga dibutuhkan penguatan kedisiplinan bagi siswa paska pembelajaran daring ini.

Berdasarkan hasil obeservasi, wawancara, serta dokumentasi, terdapat beberapa kendala teknis yang dihadapi guru dan siswa dalam pembelajaran daring.

a. Kondisi ekonomi orangtua siswa

Permasalahan teknis yang dihadapi guru dan siswa dalam pembelajaran daring adalah kondisi ekonomi keluarga. Kondisi ekonomi keluarga yang dibwah rata-rata membuat siswa tidak mampu untuk memiliki smartphone yang mendukung berjalannya platform WhatssApp. Terdapat 3 siswa kelas IV tidak memiliki smartphone yang mendukung aplikasi tersebut. Kendala tersebut tentu berdampak pada kelancaran proses belajar mengajar jarak jauh (daring). Atas permasalahan ini, guru memberi kebijakan dengan 
memperbolehkan siswa yang tidak memiliki smartphone untuk bekerjasama dengan siswa lain yang memiliki smartpone dimaksud.

Dampak lain yang dirasakan sebagai akibat dari terbatasnya kondisi ekonomi keluarga adalah kemampuan membeli paket data internet. Seperti diketahui bahwa untuk dapat mengakses aplikasi WhatssApp diperlukan sambungan internet dan otomatis membutuhkan ketersediaan paket data. Beruntungnya mulai september 2020 pemerintah memberikan bantuan kuota gratis bagi siswa dan guru.

Berdasarkan uraian tersebut, diketahui bahwa terdapat ketidakseimbangan pendidikan antar siswa yang disebabkan oleh pengaruh keluarga dan kondisi finansial. Berdasarkan penelitian yang dilakukan oleh Suputra (2020) pengaruh keluarga dan kondisi finansial keluarga mempengaruhi kesuksesan seorang siswa dalam belajar secara daring. kondisi finansial yang memadai mampu menopang secara langsug kebutuhan siswa salah satunya dalam bidang sarana dan prasarana seperti ketersediaan smartphone dan internet. Ketersediaan sarana dan prasana ini secara tidak langsung mempengaruhi kondisi psikologi siswa dalam kesipan mengikuti kegiatan belajar mengajar daring.
Sekolah sebagai pemangku kebijakan telah berusaha memberikan pelayanan optimal dalam bidang pendidikan. Menurut penuturan kepala sekolah, SDN Aengdake I telah berupaya memberikan pelayanan maksimal kepada siswa dalam hal pembelajaran daring, baik dari sisi sarana dan prasaran maupun kesiapan guru dalam mengajar. Krishan et al., (2020:1) menemukan bahwa pembelajaran daring denganfree online resources menyediakan lingkungan belajar yang memotivasi, meningkatkan keterampilanberpikir kritis dan analitis, dan menunjang interaksi sosial antara siswa dengan guru, dengan siswa lain. Dengan kata lain, upaya yang dilakukan oleh SDN Aendake I telah sejalan dengan kondisi pendidikan di Asia Tenggara.

\section{SIMPULAN}

Dari paparan diatas, dapat disimpulkan bahwa terdapat beberapa kendala yang dihadapi guru dan siswa atas perubahan metode pengajaran tatap muka (luring) menjadi jarak jauh (daring) pelajaran bahasa Inggris di SDN Aengdake I. Beberapa faktor tersebut disebabkan oleh dua faktor, yaitu faktor manajemen dan teknis. Secara detail, beberapa kendala tersebut adalah:

a. Guru menemui kendala untuk mene rapkan metode pengajaran kreatif 
b. Guru memiliki keterbatasan waktu pengajaran untuk mengelola

c. Siswa cenderung kurang disiplin pa da saat kegiatan belajar mengajar $b$ erlangsung

d. Beberapa siswa untuk kesulitan unt uk mengikuti pembelajaran daring karena kondisi ekonomi orangtua ( kepemilikan smartphone).

Terimakasih diucapkan kepada seluruh stake holder SDN Aengdake I Sumenep yang telah memberikan kesempatan bagi peneliti untuk melaksanakan penelitian mengenai kendala yang dihadapi dalam kegiatan belajar mengajar daring di masa pandemi. Semoga dengan hasil penelitian inididapatkan inovasi yang mampu menanggulangi permasalahan yang dihadapi sekolah, siswa, maupun wali siswa.

\section{DAFTAR PUSTAKA}

Aedi, N \& Amaliyah, N. (2017). Manajemen Kurikulum Sekolah. Gosyen Publishing. Yogyakarta Ariyana, Y., Bestary, R., \& Mohandas, R. (2018). Buku pegangan pembelajaran berorientasi pada keterampilan berpikir tingkat tinggi. Direktorat Jenderal Guru dan Tenaga Kependidikan Kementerian Pendidikan dan Kebudayaan Hak.
Bazimaziki, G. (2020). Challenges in using ICT Gadgets to cope with effects of COVID-19 on Education: A short survey of online teaching Literature in English. Journal of Humanities and EducationDevelopment

Byun, S., \& Slavin, R. E. (2020). Educational Responses to the COVID-19 Outbreak in South Korea.SSRN Electronic Journal. https://doi.org/10.2139/ssrn.3652607 Huang, R., Tlili, A., Chang, T. W., Zhang, X., Nascimbeni, F., \& Burgos, D. (2020).

Disrupted classes,undisrupted learning during COVID-19 outbreak in China: application of open educational practices andresources. Smart Learning Environments, 7(1). https://doi.org/10.1186/s40561-020$\underline{00125-8}$

Krishan, I. A., Ching, H. S., Ramalingam, S., Maruthai, E., Kandasamy, P., Mello, G. De, Munian, S., \& Ling, W. W. (2020). Challenges of Learning English in 21st Century: Online vs. Traditional During Covid19.Malaysian Journal of Social Sciences and Humanities (MJSSH)

Pohan, A. E. (2020). Konsep pembelajaran daring berbasis pendekatan ilmiah. Penerbit CV. SARNU UNTUNG. 
Ramadhani, R., Wirapraja, A., Sulaiman, O. K., Safitri, M., Jamaludin, J., Gandasari, D., ... \& Ahdiyat, M. (2020). Platform Asesmen untuk Pembelajaran Daring: Teori \& Praktik. Yayasan Kita Menulis.

Sugiyono. (2007). Metodologi Penelitian Pendidikan. Bandung: Alfabeta Suputra, Putu, at al (2020). Kelas Daring Bahasa Inggris di Masa Pandemi: Sebuah Tantangan Pembelajaran. SEMINAR NASIONAL RISET INOVATIF.

Yuliani, M., Simarmata, J., Susanti, S. S., Mahawati, E., Sudra, R. I., Dwiyanto, H., ... \& Yuniwati, I. (2020). Pembelajaran Daring untuk Pendidikan: Teori dan Penerapan. Yayasan Kita Menulis. 